\title{
Comparison between Calcimetric and Titrimetric Methods for Calcium Carbonate Determination
}

\author{
Pakhshan M. Maulood, Akram O. Esmail*, Mohammed S. S. Dohuki, Dalshad A. Darwesh
}

Soil and Water Department, College of Agriculture, Salahaddin University, Erbil, Iraq.

Email: *arez96y@yahoo.com

Received May $17^{\text {th }}, 2012$; revised June $20^{\text {th }}, 2012$; accepted July $5^{\text {th }}, 2012$

\begin{abstract}
This study was conducted during 2008-2009, which included calcium carbonate determination from 84 locations (40 soil samples from Erbil, 24 samples from Sulaimani and Kirkuk in addition to 20 samples from Duhok) using calimetric and titration method. The results indicated to significance correlation coefficient between the studied methods or it means that the results of both methods are similar.
\end{abstract}

Keywords: Calcium Carbonate; Calcimeter; Calcareous Soil

\section{Introduction}

Most soils of agricultural areas are calcareous and have an alkaline reaction. $\mathrm{pH}$ of calcareous soils is mainly controlled by the amount of calcium carbonate in the soil profile and often is fluctuating between 7.5 to 8.2. Existence or absence of calcium carbonate has an important effect on soil $\mathrm{pH}$ and therefore, controlling many chemical reactions in relation to nutrient availability for plants and mobility of these elements in soil [1]. Carbonate is a natural constituent of many soil in the world, most carbonate minerals found in Iraqi soils are calcite $\left(\mathrm{CaCO}_{3}\right)$ and represent $90 \%-95 \%$ of total soil carbonates [2]. The distribution and amount of carbonates influence soil fertility. The increase of calcium carbonate in soil usually leads to many problems related to fertilization and nutrient availability. The extent and rate are affecting by the amount of carbonates in the soil, the chemical and physical nature of the carbonates (e.g., particle size and mineralogy) $[3,4]$ Carbonates exert a major effect on soil chemical properties of calcareous soils, like nutrient availability and phosphorus fixation due to chemical fixation of $70 \%-90 \%$ of applied phosphorus fertilizer to the soil [5]. Soil survey staff [6] indicated to increase in soil $\mathrm{pH}$ with increasing soil $\mathrm{CaCO}_{3}$ content. Some attempts have been done to evaluate methods of carbonate determination in arid and semiarid soils including calcareous soils [7-10]. A suitable, accurate method of determining limestone is required whenever quantitative measurements are sought, such as in soil fertility problems where limestone dissolution rates are to be deter-

"Corresponding author. mined, or where lime recommendation procedures take into account residual limestone [11]. The aim of this study is to compare between two methods of $\mathrm{CaCO}_{3}$ determination (Acid neutralization method and calcimetric method).

\section{Materials and Methods}

The studied soil samples were taken from 84 locations (40 soil samples from Erbil, 24 samples from Sulaimani and Kirkuk in addition to 20 samples from Duhok), during 2008-2009 (Figures 1-3). Soils were air dried ground and sieved through $2 \mathrm{~mm}$ sieve. The equivalent calcium carbonate $\left(\mathrm{E}-\mathrm{CaCO}_{3}\right)$ was determined using $0.5 \mathrm{M} \mathrm{HCl}$ for dissolution of $\mathrm{CaCO}_{3}$ and determined between the two titration of the excess acid by using $0.2 \mathrm{M} \mathrm{NaOH}$ as mentioned by [12]. The second method of $\mathrm{E}-\mathrm{CaCO}_{3}$ determination was using calcimeter method as mentioned by [13]. The simple correlation coefficient $n(r)$ was determined between the two studied methods [14].

\section{Results and Discussion}

The soils $\mathrm{CaCO}_{3}$ content of the studied locations were ranged from (20 - 365.3 $\mathrm{g} \cdot \mathrm{Kg}^{-1}$ soil) for the soils of Erbil, Sulaimani and Duhok respectively (Tables 1-3). The statistical analysis indicated that the correlation co- efficient values (r) between the studied two methods for the three locations (Erbil, Sulaimaniya and Duhok) were $\left(0.993^{* *}, 0.998^{* *}\right.$ and $\left.0.994^{* *}\right)$ respectively (Figures 4-6). It means there is a significance correlation between calcimetric and titrimetrc method, or it means the results of both methods are similar and both methods 
Table 1. Shows determination of calcimetric and titrimetric methods of calcium carbonate in soil t of Erbil governorate.

\begin{tabular}{|c|c|c|c|c|c|c|c|}
\hline Sites No. & Locations & Calcimetric Method & Titrimetric Method & Sites No. & Locations & Calcimetric Method & Titrimetric Method \\
\hline 1 & Kalak & 287 & 274 & 21 & $\begin{array}{l}\text { Halgort } \\
\text { Mountain }\end{array}$ & 20 & 25 \\
\hline 2 & Guwer & 298.1 & 297.5 & 22 & Akoyan & 227.3 & 223 \\
\hline 3 & Yarmcha & 312.9 & 316 & 23 & Rosty & 37.3 & 35 \\
\hline 4 & Mala-Qara & 253 & 263 & 24 & Hasarot & 209.3 & 199.5 \\
\hline 5 & Erbil & 246.4 & 239.2 & 25 & Choman & 64.7 & 64 \\
\hline 6 & Qushtapa & 276.3 & 289 & 26 & Rayat & 41 & 53.5 \\
\hline 7 & Derband & 137 & 128.5 & 27 & Azadi & 209.3 & 191.8 \\
\hline 8 & Degala & 175.2 & 188 & 28 & Haji-Omran & 152 & 195 \\
\hline 9 & Koysenjaq & 141.6 & 153.5 & 29 & Haji-Omran & 93.1 & 91 \\
\hline 10 & Koysenjaq & 239.7 & 225 & 30 & Chame-Beaje & 211.1 & 202 \\
\hline 11 & Qarasenj & 140.8 & 140 & 31 & Khalan & 216.6 & 202 \\
\hline 12 & Bastora & 290.9 & 292.3 & 32 & Mergasor & 201.4 & 193 \\
\hline 13 & Shaqlawa & 209.1 & 198 & 33 & Malman & 291.2 & 292.3 \\
\hline 14 & Mama-Jelka & 67.1 & 72.5 & 34 & Soran Village & 108.3 & 112 \\
\hline 15 & Harer & 193 & 187.5 & 35 & Ashkafta & 112 & 122 \\
\hline 16 & Spelek & 79.1 & 71.5 & 36 & Rezan & 53.3 & 51.5 \\
\hline 17 & Jundeyan & 220.3 & 231 & 37 & Barzan & 361.4 & 362 \\
\hline 18 & Zar-Gali & 219.9 & 205.5 & 38 & Maran & 18.6 & 16 \\
\hline 19 & Rawndouz & 138.1 & 131.8 & 39 & Peran & 15 & 18.5 \\
\hline 20 & Soran & 55.9 & 55 & 40 & Mandan & 161 & 171 \\
\hline
\end{tabular}

Table 2. Shows determination of calcimetric and titrimetric methods of calcium carbonate in soils of Sulaymani and Kirkuk governorate.

\begin{tabular}{|c|c|c|c|c|c|c|c|}
\hline Sites No. & Locations & Calcimetric Method & Titrimetric Method & Sites No. & Locations & Calcimetric Method & Titrimetric Method \\
\hline 1 & Ranya & 44.5 & 43.5 & 13 & Serwan & 89.4 & 81.5 \\
\hline 2 & Ranya & 63.4 & 65 & 14 & Halabja & 108.1 & 101 \\
\hline 3 & Qalat Dizah & 16.8 & 18.5 & 15 & Khormal & 83.9 & 88.5 \\
\hline 4 & Haybat Sultan & 163.9 & 170 & 16 & Bayara & 37.8 & 40 \\
\hline 5 & Kani Watman & 164 & 170 & 17 & Balkha & 49 & 55.5 \\
\hline 6 & Kelka smaqa & 137.9 & 132.5 & 18 & Tawela & 22.4 & 28.5 \\
\hline 7 & Dukan & 294.9 & 292.5 & 19 & Altun Kupri & 201.6 & 199.9 \\
\hline 8 & Basneh & 66 & 59 & 20 & Kirkuk & 153 & 156 \\
\hline 9 & Qalat Cholan & 65.2 & 70.5 & 21 & Kirkuk & 192.2 & 192.3 \\
\hline 10 & Sulaymaniyah & 190.4 & 193 & 22 & Chemano & 317.73 & 313 \\
\hline 11 & Said Sadek & 145.3 & 151 & 23 & Qara Hanjer & 309.9 & 311 \\
\hline 12 & Derbandikhan & 253.3 & 252.3 & 24 & Chamchamal & 242.6 & 253 \\
\hline
\end{tabular}


Table 3. Shows determination of calcimetric and titrimetric methods of calcium carbonate in soils of Duhok governorate.

\begin{tabular}{|c|c|c|c|c|c|c|c|}
\hline Sites No. & Locations & Calcimetric Method & Titrimetric Method & Sites No. & Locations & Calcimetric Method & Titrimetric Method \\
\hline 1 & Qandil bridge & 258.2 & 251 & 11 & Duhok & 246.1 & 251 \\
\hline 2 & Gawelan & 365.3 & 360 & 12 & Zaweta & 203.1 & 192.5 \\
\hline 3 & Aqrah & 160.3 & 172.8 & 13 & Mam-Yazden & 339.4 & 329.6 \\
\hline 4 & Gali-Zanta & 323.4 & 325 & 14 & Swaratuka & 185.5 & 192 \\
\hline 5 & Lalesh mountain & 114.2 & 101.8 & 15 & Solaf & 196 & 192 \\
\hline 6 & Atrush & 248.8 & 242.5 & 16 & Serseng & 193.6 & 192.2 \\
\hline 7 & Atrush mountain & 304.4 & 306 & 17 & Serseng & 226.2 & 221.8 \\
\hline 8 & Baadrae & 242.1 & 242.3 & 18 & Kani Chnarkae & 163.9 & 170 \\
\hline 9 & Gali-Derkae & 315.8 & 320 & 19 & Qadash & 201.7 & 192.3 \\
\hline 10 & Duhok & 247.3 & 251 & 20 & Zakho & 251.3 & 250 \\
\hline
\end{tabular}

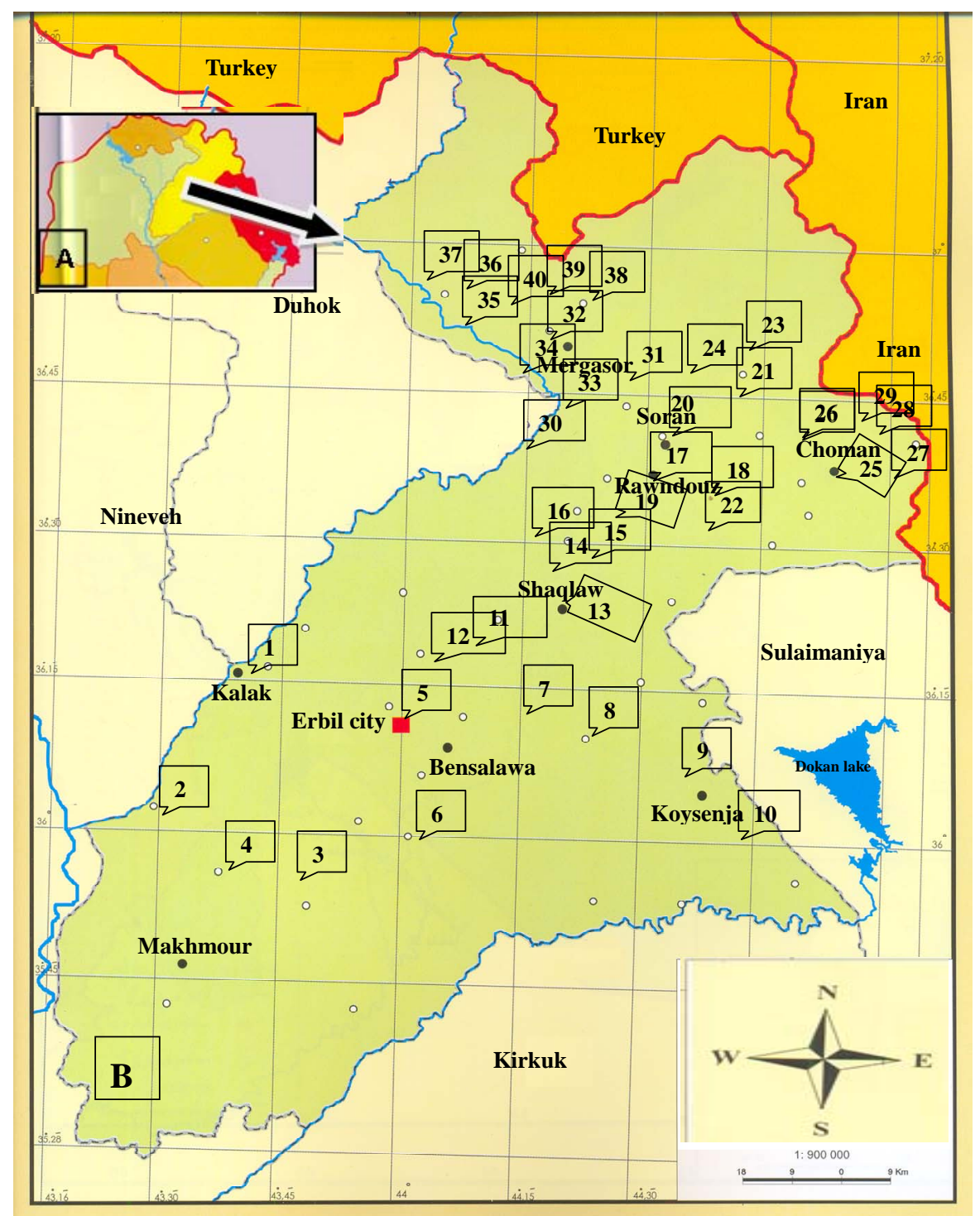

Figure 1. Shows: (A) Map of northern governorate of Iraq; (B) Erbil governorate, sampling sites. 


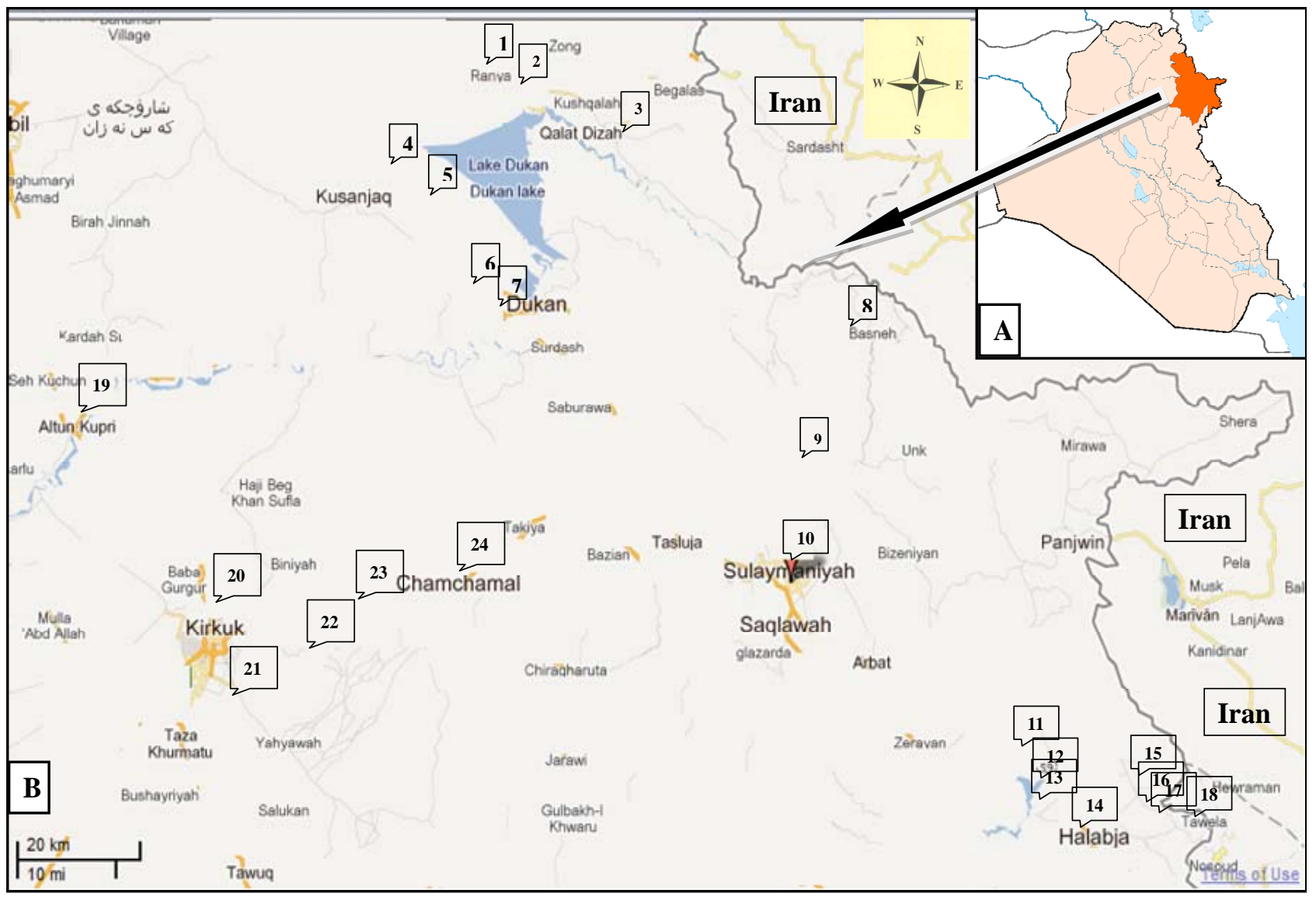

Figure 2. Shows: (A) Map of Iraq; (B) Sulaymaniyah and Kirkuk governorates, sampling sites.

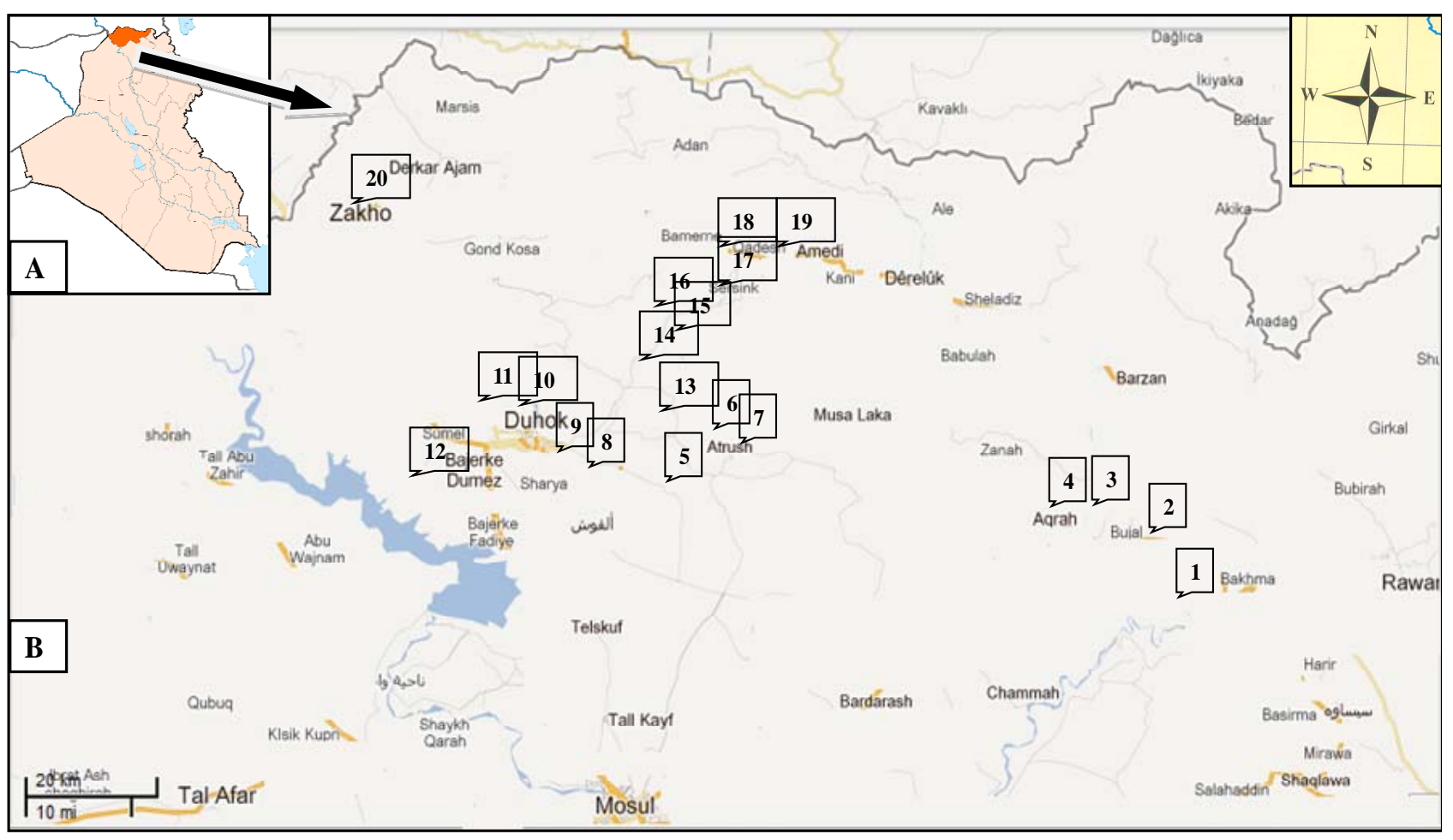

Figure 3. Shows: (A) Map of Iraq; (B) Duhok governorate, sampling sites. 


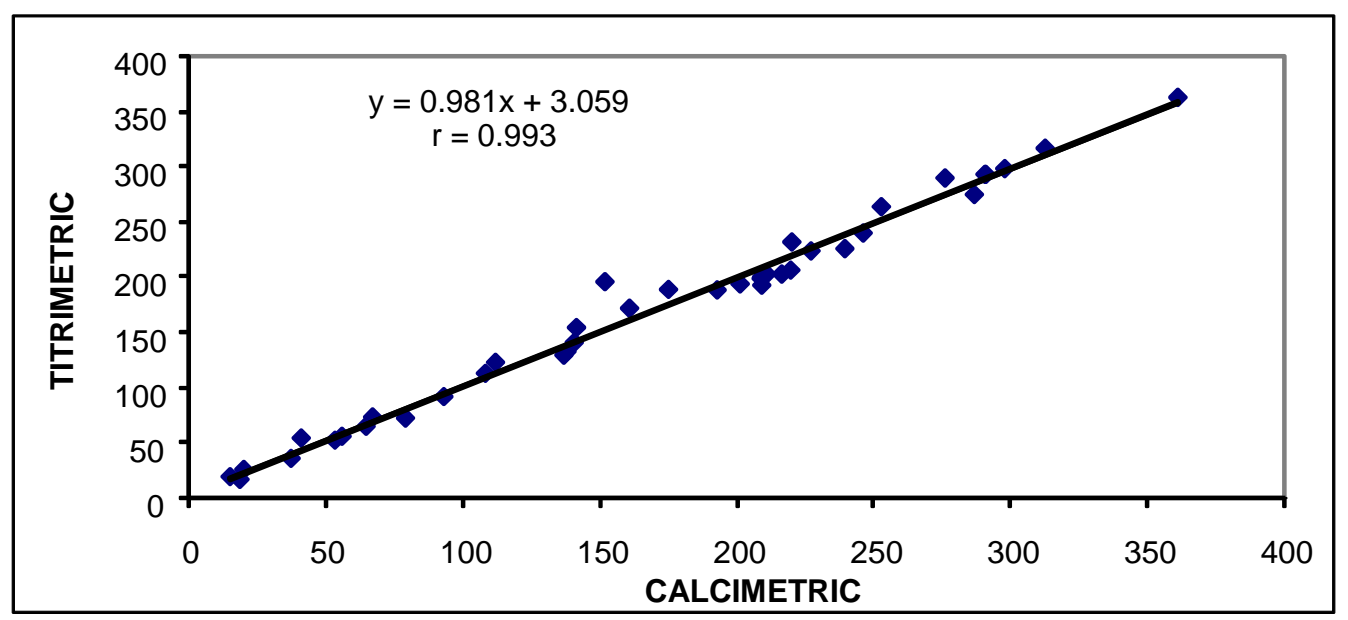

Figure 4. The relationship between titrimetric and calcimetric methods of calcium carbonate determination in soil of Erbil governorate.

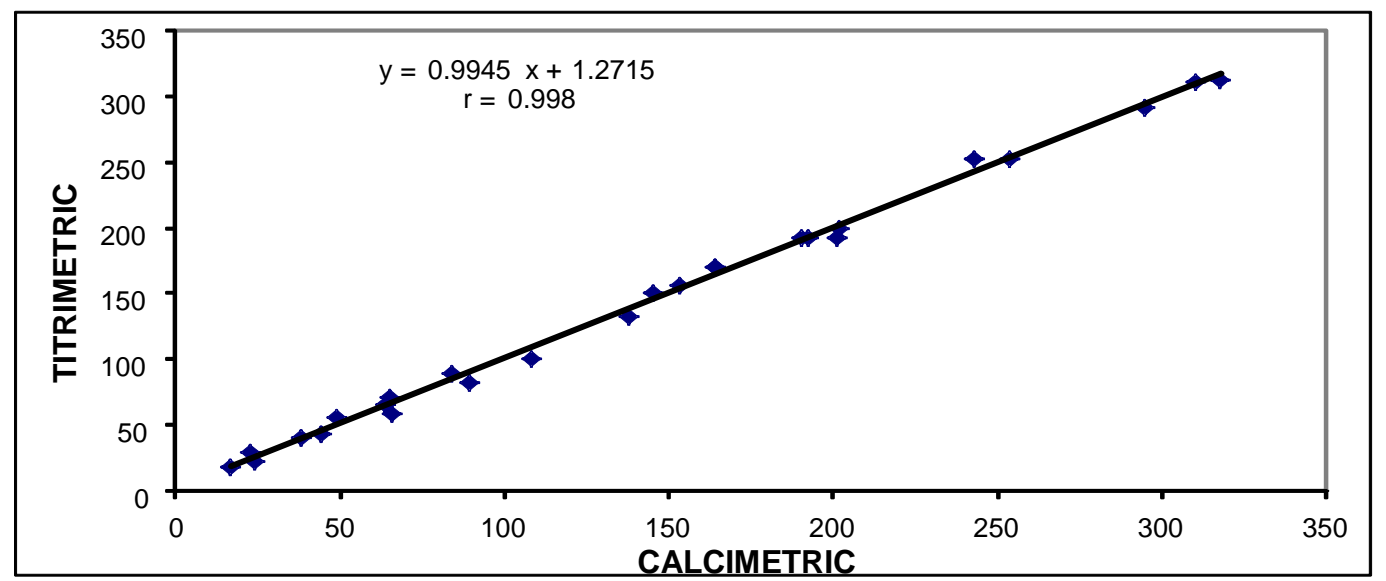

Figure 5. The relationship between titrimetric and calcimetric methods of calcium carbonate determination in soils of Sulaymani and Kirkuk governorates.

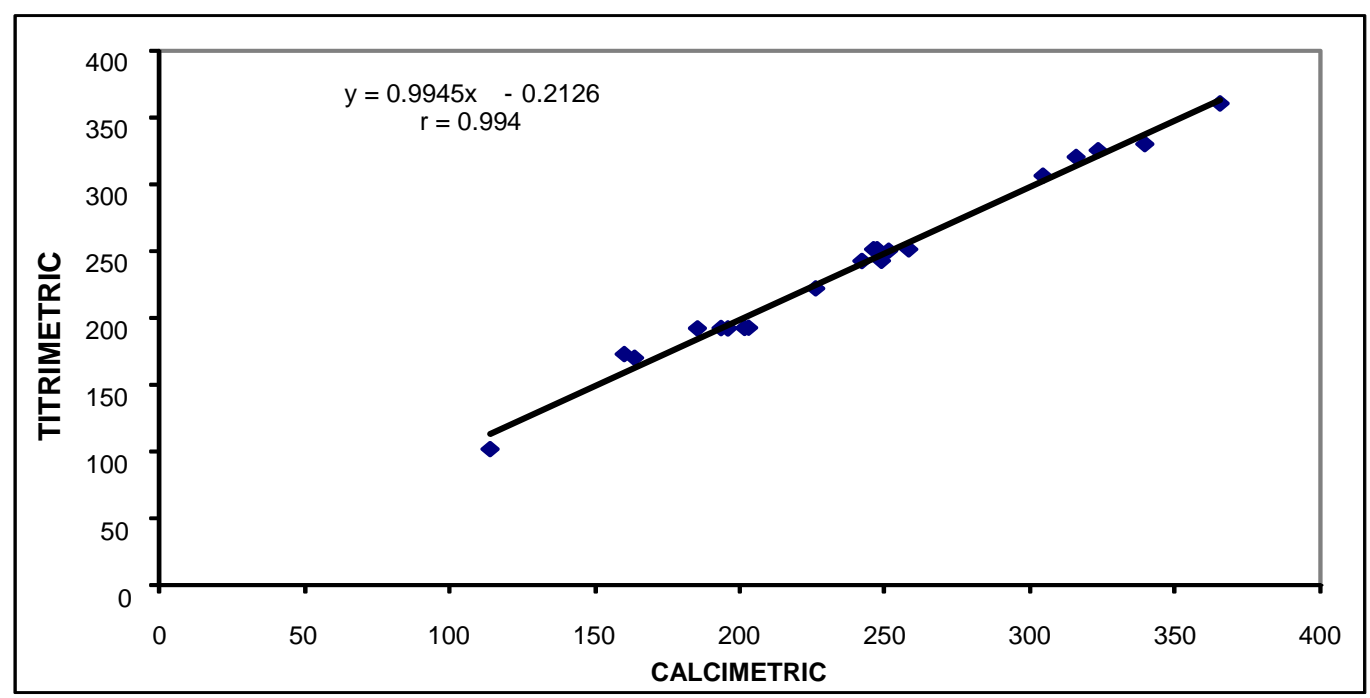

Figure 6. The relationship between titrimetric and calcimetric methods of calcium carbonate determination in soils of Duhok governorate. 
Table 4. A comparison of equivalent calcium carbonate determination by two methods in soil samples of Kurdistan Region governorate, data represented as (mean $\pm \mathrm{SE}$ ).

\begin{tabular}{ccc}
\hline Governorate & Calcimetric Method & Titrimetric Method \\
\hline Erbil & $169.62 \pm 14.78$ & $169.47 \pm 14.61$ \\
Sulaimaniya and Kirkuk & $139.90 \pm 18.22$ & $140.40 \pm 18.15$ \\
Duhok & $239.33 \pm 14.61$ & $237.79 \pm 14.60$ \\
\hline
\end{tabular}

have the same scientific base. The differences shown in (Table 4) between mean values of $\mathrm{E}-\mathrm{CaCO}_{3}$ content of soil samples measured by the two mentioned methods are non significance. A little difference observed between two methods for soil samples of Erbil, SulaimaniyaKirkuk governorates that reached to 0.15 and -0.5 respectively. While the differences was 1.54 unit for Duhok soil samples. Generally, soil samples for $\mathrm{E}-\mathrm{CaCO}_{3}$ content were increased gradually from SulaimaniyaKirkuk, to Erbil toward Duhok governorate.

\section{REFERENCES}

[1] F. Sarmadian, A. Keshavarzi and A. Malekian, "Continous Mapping of Topsoil Calcium Carbonate Using Geostatistical Techniques in a Semi-Arid Region," Australian Journal of Crop Science, Vol. 4, No. 8, 2010, pp. 603608.

[2] S. Al-Kaysi, "Effect of Wetting-Drying Cycles of Soils on Carbonate and Phosphorus Adsorption. Physical and Chemical Properties of Carbonate," 5th Scientific Science Research Council (Baghdad, Iraq), Vol. 1, No. 2, 1989, pp. 29-36.

[3] Y. S. Hamid, "Dissolution Kinetics of Carbonates in Soil," Ph.D. Dissertation, Szent Istvan University, Hungary, 2009.

[4] M. C. del Campillo, J. Torrent and R. H. Loeppert, "The Reactivity of Carbonates in Selected Soils of Southern Spain," Geoderma, Vol. 52, No. 1-2, 1992, pp. 149-160. doi:10.1016/0016-7061(92)90080-Q

[5] J. L. Havlin, J. D. Beaton, S. I. Tisdale and W. L. Nelson,
"Soil Fertility and Fertilizers," 7th Edition, Pearson Education Inc., Singapore City, 2007.

[6] Soil Survey Staff, "Soil Taxonomy," USA Printing Office, Washigton DC, 1999.

[7] N. A. K. Hassan and B. H. Al-Tawil, "A Study on Lime Status of Iraq Soils," Ministry of Higher Education and Scientific Research, Baghdad, 1973.

[8] W. M. Van Lierop and A. F. Mackenzie, "Carbonate Determination in Organic Soils," Canadian Journal of Soil Science, Vol. 54, No. 4, 1974, pp. 457-462.

[9] R. E. Nelson, "Carbonate and Gypsum," Agronomy Journal, Vol. 9, 1982, pp. 181-197.

[10] Y. El-Mahi, I. S. Ibrahim, H. M. Abd-Majid and A. M. Eltilib, "A Simple Method for Determination of Calcium Carbonate in Soils," Soil Scientific Society American Journal, Vol. 51, No. 11, 1987, pp. 1152-1155.

[11] F. Lamas, C. Irigaray, C. Oteo and J. Chacon, "Selection of the Most Appropriate Method to Determine the Carbonate Content for Engineering Purposes with Particular Regard to Marls," Engineering Geology, Vol. 81, No. 1, 2005, pp. 32-41. doi:10.1016/j.enggeo.2005.07.005

[12] A. Dreleimanis, "Quantities Gasometric Determination of Calcite and Dolomite by Using Chittick Apparatus," Journal of Sedimentary Petrology, Vol. 32, No. 3, 1962, pp. 20-29.

[13] S. I. A. Al-Sulaivani, "Physicochemical Behavior of Ortho and Pyrophosphate in Some Calcareous Soils from Northern of Iraq," Ph.D. Dissertation, University of Baghdad, Baghdad, 1993.

[14] V. Gupta, "SPSS for Beginners," VJBooks Inc. Publishers, 1999. www.vgupta.com 